\title{
1942 M. „EKUMENINIS“ GIESMYNAS IR JO IDIEGIMO SUNKUMAI
}

\author{
Darius Petkūnas \\ Klaipèdos universitetas, Helsinkio universitetas
}

\begin{abstract}
Anotacija
1942 m. Reformatu bažnyčios kolegija atspausdino 1937-1940 m. Liuteronų bažnyčios parengta giesmyna bendrine lietuviu kalba, kurio po $1941 \mathrm{~m}$. jvykusios repatriacijos sudaryta naujoji konsistorija atsisake. , Evangeliku giesmynas su maldomis “ turejjo tapti oficialiuoju Reformatu bažnyčios giesmynu. Išimties tvarka knyga leista naudotis Kauno ir kitoms karo laikotarpiu atsikūrusioms liuterony parapijoms. 1943 m. liuteronu konsistorija nusprendè iš naujo suredaguoti oficialų bažnyčios giesmyna „,Pagerintos giesmių knygos “, tačiau darbą sutrukde 1944 m. karo veiksmai ir sovietine okupacija. Naujo giesmyno ịdiegima Reformatu bažnyčioje komplikavo superintendento kun. Adomo Šerno apostaze. Reformatu parapijos iš šios knygos pradejo giedoti tik $1986 \mathrm{~m}$.

PAGRINDINIAI ŽODŽIAI: liuteronai, reformatai, giesmynas.
\end{abstract}

\begin{abstract}
In 1942 the Lithuanian Reformed Collegium resurrected the Lutheran ecumenical hymnal project which the Lutherans had dropped after the repatriation of 1941. The Lithuanian book appeared in an abridged version entitled: Evangeliku Giesmynas su Maldomis (Evangelical Hymnal with Prayers) later that year. By special permission of the Lutheran consistory, only the Kaunas Lutheran congregation used this hymnal. In 1943 the Lutheran pastors established their own hymnal commission to produce a suitable Lutheran hymnal, based on the Pagerintos giesmiu knygos (Improved Books of Hymns), the official Lithuanian Lutheran hymnal at that time. The soviet occupation made it impossible to continue the project. The book was not popular in the Reformed Church, especially after the apostasy of Adomas Šernas. It was only in 1986 that it was made the official hymnal of the Lithuanian Reformed Church because copies of the old official hymnal were no longer available.

KEY WORDS: Lutherans, Reformed, hymnal.
\end{abstract}

\section{Ivadas}

Lietuvos Liuteronų bažnyčios konsistorija 1937 m. inicijavo projektą, kurio tikslas buvo išleisti giesmyną bendrine lietuvių kalba. Kadangi tuo metu reformatų kun. Adomas Šernas jau buvo suredagavęs ar iš vokiečių kalbos 
išvertęs nemažai liuteroniškų giesmių, konsistorija nusprendẻ pasinaudoti jo darbu. Tuo metu abiejose bažnyčiose plito unionistinis judejjimas, kuri ypač skatino ekumeninè Lietuvių evangelikų sąjunga. Giesmynas turejjo tapti pirmąja ekumenine giesmių knyga, pakeitusia iki tol naudotus oficialiuosius giesmynus - liuteronu „Pagerintas giesmių knygas“ ir reformatų „Giesmyną su maldų priedu“. Oficialus giesmyno leidejas buvo liuteronų konsistorija. Jos sudaryta techninè komisija peržiūrèjo kun. A. Šerno suredaguotas giesmes. Dalis jų pripažintos tinkamos giedoti, kitos - taisytinos arba atmestinos. Dali giesmių komisija paèmè iš „Pagerintų giesmių knygų“ ir suredagavo. Projektą iš dalies finansavo Lietuvos Respublikos švietimo ministerija. Vadovaudamasi jos rekomendacijomis, konsistorija sudare Redakcijos komisiją, ị kurią pakvietė liuteronų ir reformatų bažnyčių vadovus bei projekte dalyvavusius asmenis.

1940 m. pradžioje giesmynas parengtas spaudai, bet ji atspausdinti sutrukdè sovietinè okupacija ir religinès spaudos laisvę suvaržęs sovietinis ateistinis režimas. Nacių okupacijos laikotarpiu bažnyčioms grąžinta religijos išpažinimo laisvė. Vèl atsivèrẻ galimybė atspausdinti ekumenini giesmyną, bet po $1941 \mathrm{~m}$. liuteronų repatriacijos suformuota naujoji konsistorija ne tik išsižadèjo ankstesnès konsistorijos iniciatyvos, bet ir visiškai pasitraukè iš giesmyno projekto.

Straipsnyje nagrinėjamos priežastys, paskatinusios liuteronų konsistoriją atsisakyti jos pirmtakès inicijuoto giesmyno projekto, aptariama Reformatu bažnyčios iniciatyva atspausdinti sutrumpintą giesmyno variantą bei Liuteronų bažnyčios požiūris ị 1942 m. knygą. Skaitytojas supažindinamas su liuteronų konsistorijos pastangomis redaguoti „Pagerintas giesmių knygas“. Be to, aprašomas sudètingas $1942 \mathrm{~m}$. giesmyno diegimo reformatų parapijose procesas, aptariamas šios knygos poveikis Liuteronų bažnyčios himnologijai.

Straipsnis parengtas, remiantis archyviniais dokumentais, kurie saugomi Lietuvos centriniame valstybės archyve (toliau - LCVA), Lietuvos evangelikų liuteronų Bažnyčios konsistorijos archyve (toliau - KA) ir Vyskupo Jono Kalvano archyve (toliau - JKA) ${ }^{1}$.

1 Šis straipsnis yra tęsinys $2012 \mathrm{~m}$. autoriaus publikuoto straipsnio „Prieškario Liuteronų Bažnyčios pastangos išleisti giesmyną bendrine lietuvių kalba“ (Petkūnas, 2012), kuriame aprašytas $1942 \mathrm{~m}$. giesmyno parengimo leidybai procesas. 


\section{Konsistorijos sprendimas pasitraukti iš giesmyno projekto}

1942 metų pavasarị Reformatų bažnyčios kolegija kreipėsi į Liuteronų bažnyčios konsistoriją, siūlydama kartu atspausdinti 1940 m. spaudai parengtą pirmaji ekumeninį bažnyčių giesmyną literatūrine kalba. 1942 m. balandžio 30 d. konsistorija ị pasiūlymą atsakè vienu sakiniu: „Prie Šerno taisytų giesmių knygų išleidimo neprisidèti.“ Tik jos pirmininkas kun. Erikas Leijeris laikèsi kitos nuomonès. Protokolo apačioje jis užrašè:

„Lietuvos ev. liuteronims ir ev. reformatams naujai leidžiamam giesmynui pritariu, nes jis buvusios konsistorijos ir kolegijos buvo po ilgo darbo ir kruopštaus tikrinimo priimtas spausdinimui. Be to, šiuo metu skaitau, kad tai yra didelis įnašas lietuvių evangelikų dvasiniame bei tautiniame gyvenime, ypatingai formuojant mūsų jaunosios kartos dvasinį bei tautini akiratị. Taip pat šis giesmynas turès pagilinti evangelikų liuteronų ir evangelikų reformatų glaudesnị bendradarbiavimą Viešpaties Dievo vynuogyne. Todèl te kiekvienas nuoširdžiai ir tikrai ieškantis šiame giesmyne surandą tą, kuris vieninteliai jo ištroškusią sielą gali atgaivinti, būtent Viešpatị Dievą“" (Lietuvos..., 1942).

Kas gi privertė konsistoriją priimti tokị prieštaringą sprendimą?

\section{Liuteronų požiūris ị giesmyną bendrine lietuvių kalba}

Prieškarinès konsistorijos sprendimas išleisti giesmyną literatūrine lietuvių kalba buvo sveikintinas, tačiau ne visiems priimtinas, nes bendrinè kalba daliai Lietuvos liuteronų buvo neiprasta. Šia tarme mišios buvo švenčiamos tik Kaune, Jurbarke ir Suvalkijoje, tuo tarpu Užnemunėje liuteronų daugumą sudare vokiečiai, tad tik nedidelè liuteronų dalis ten meldèsi lietuviškai. Daugiausia lietuvių tautybės liuteronų gyveno Tauragès ir Kretingos regionuose, bet jų tarmé skyrėsi nuo Suvalkijoje bei Kaune vartotos bendrinès kalbos. Paskutinioji tarpukario konsistorija optimistiškai manè, kad vakarų ir šiaurès vakarų lietuvių liuteronų parapijos ši giesmyną priims.

Pirmoji kritika, nukreipta prieš giesmyno projektą, pasigirdo 1939 m. vasarą. Konsistorijos reikalų vedèjas Albertas Juozuvaitis straipsnyje „Ar nu- 


\section{Pagerintos \\ (Giefmint Gillyngos, \\ tuxiofe \\ brangiaulios fenos ir naujos}

Giefmès

iurapytos

Diemui ant Barbès

ir

Sietumininfams ant

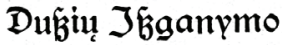

podxa ug $\mathfrak{x}$

Maloụ Knygomis

bei nauju treçioftos Dalies \$apildymu

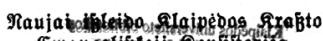

Emangetiptoinisonfitantits

1936 steltate

Spaupinta ipautumeje "Rituania"

Rlaipēba, \$alangos gatmé 23/24

Mažosios ir Didžiosios Lietuvos liuteronų giesmynas, 1936 m. laida matytame išleisti naujame lietuviškame evangeliškame giesmyne giesmių vertimas yra geras?“ rašè: „Atsiranda vienas kitas, visuomeneje skleisdamas gandus, kad mums, evangelikams lietuviams, senasis giesmynas esąs artimesnis, visiems priprastas ir geras, o naujasis giesmynas esąs nereikalingas. Taip gali kalbèti tokie žmonès, kurie užgimę yra ne kurti, o viską griauti ir iš tų griuvèsių imti sau žemišką naudą, sėdint visuomet ant dviejų kèdžių“ (Juozuvaitis, 1939, p. 104).

Griežčiau kritikuoti naujo giesmyno projektą pradejjo sakytojai - neordinuoti Dievo žodžio skelbejjai, tarp jų - Ansas Baltris ir Janis Sprogis iš Klaipèdos. Pastarasis prieš „Pagerintų giesmių knygų“ redagavimą nebuvo kategoriškai nusiteikęs, bet norejo, kad naujoji redakcija per daug nenutoltų nuo originalo. „Šita lūkestimi gyvena ir šiandieniniai pietistai surinkimininkai“, - rašè jis 1938 metais. „Šiandien jie laiko sentèvių lobynu savo giesmių knygą. Iš jų išbraukus slavizmą ir pritaikius prie vietinès pažanginès kalbos,

bet su meile ir gerbiant tradiciją, tai galima ir atrasti pritarimo ir supratimo." Sakytojams buvo nepriimtinas konsistorijos sprendimas redaguoti giesmes griežtai laikantis bendrinès kalbos taisyklių. Dèl tokios redakcijos gerokai keitėsi giesmių tekstai. Sakytojams toks požiūris reiškẻ „lietuviškai tikybiškos praeities panaikinimą“ (Sprogis, 1938). J. Sprogio ir A. Baltrio nuomone, giesmyno techninès komisijos parengtos giesmès neteko „tikybinio jausmingumo“. Jose nebeliko mažybinių maloninių žodžių, tokių kaip galvelè, dūšelè, saldžiausias, Jézulytis ir kt. 
A. Baltris tuo metu èjo „misijos diakono“ pareigas ir aptarnavo Kauno Šančių liuteronų parapiją. Išgirdęs apie spaudai baigiamą rengti knygą, jis paliko misijos vietą ir laikinai apsigyveno Kretingoje. Ten èmė kretingiškiams skalbti, kad konsistorija ir jų kun. Adomas Gelžinius iš jų nori atimti senąsias giesmių knygas, o vietoj jų ịteikti giesmyną „nesuprantama“ kalba. Dalis parapijiečių kun. A. Gelžiniui èmė atvirai reikšti pretenzijas. Pastarasis A. Baltrio veiklos klausimą iškẻlè konsistorijoje. 1940 m. sausio 9 d. konsistorija nusprendè, kad A. Baltris „suerzino Kretingos ir kitu parapijų kai kuriuos žmones prieš parapijos kunigą ir konsistorijąa“. Konsistorija atėmè iš jo misijos diakono pareigybę ir uždraudè ,rašinèti kiršinančio turinio raštus bažnytiniais reikalais“ (Gudaitis, 1957, p. 364; Lietuvos..., 1940, 1. 315-316). Šis sprendimas A. Baltrị dar labiau paskatino viešai kritikuoti giesmyno projektą ir ryžtingiau ginti senąsias lietuvininkų giesmių knygas. 1941 m. referate „Surinkimai Didžiojoje Lietuvoje“ jis išdèste savo poziciją:

„Šiandien jie [sakytojai] visi pripažįsta reikalą, tų knygų kalbai pritaikinti kalbos pasaugai. Net ir dèl [gotikinių] raidžių jie žūtbūtinai nekovos. Bet jie priešinasi žūtbūtinai kiekvienoms pastangoms, jiems kitus kokius Biblijos ir giesmynų vertimus primesti. Jie tam priešinasi, kaip priešinasi kiekvienas gyvas sutvėrimas pasijusdamas ir išvydęs, kad kuo nors žudomas. Kiekvienuose naujuose jų senujų ir įsitradicinusiųjų Biblijų ir giesmių vertimuose jie natūraliai mato iškištą peilị, durklị, žudantị jų dvasiškaji gyvastị ir gyvenimą, ir dèl to aišku, kodèl jie žūtbūtinai ir taip vieningai tam priešinasi“ (Gaigalaitis, 1998, p. 26).

Nepasitenkinimą projektu reiškė ir parapijos. $1938 \mathrm{~m}$. Tauragės parapijos kun. Augustas Vymeris ir tarybos nariai kreipèsi ị konsistoriją su prašymu „daryti žygių, kad nebūtų išleistas vienas bendrai giesmynas reformatams ir liuteronims, bet du atskiru giesmynu - vienas reformatams, antras liuteronims“. Jų nuomone, bendras abiejų bažnyčių giesmynas turès talpinti liuteronų ir reformatų giesmes, dẻl ko bus per didelès apimties ir nepatogus naudoti. Be to, tauragiškiai akcentavo jų liuteronišką tapatybę. , Liuteronys savo giesmyne reformatų giesmių giedoti vis tiek nerastų reikalingumo, bet nuo savo giesmyno ir maldų neatsisakys." Kun. Vymeris ir taryba paragino konsistoriją 
rūpintis vien tik liuteroniško giesmyno parengimu, kuris „,būdamas gana turiningas neišeitų per storas ir per brangus“" (Tauragès..., 1938).

Netrukus ị valstybès institucijas èmè plūsti skundai. 1939 m. gruodžio 14 d. raštą švietimo ministrui įteikè penki Jurbarko parapijos nariai. Jie pastebejo, kad naujame giesmyne tèra 500 giesmių, o senosiose giesmių knygose net 700. Naujos giesmès imtos ne iš senojo giesmyno, bet „svarbiausia, kad tos pačios taip labai pakeistos, kad visai negalima pažinti“". Labiausiai jurbarkiškius piktino naujojo giesmyno „laikraštinè kalba“. „Mielai džiaugtumès, kad būtų išmesti svetimžodžiai, pataisyta kalba, bet ne sauvališkai viskas, kas lietuviui ev. liuteroniui brangu pakeista nudèvèta laikraštine kalba.“

Po dviejų dienų, gruodžio 16 d., tie patys parapijiečiai parašè panašaus turinio raštą Ministrui Pirmininkui. Jie skundèsi, kad ,asmenys, kuriems buvo pavestas giesmių paruošimas, jas per daug nutolino nuo senojo teksto, tų giesmių, kurias mūsų tèvai jau šimtmečius gieda ir kurias daugelis beveik atmintinai moka“. Jie prašè Ministro Pirmininko duoti nurodymą atsakingiems asmenims iš naujo redaguoti giesmes išsaugant senosios kalbos groži. Pakanka pašalinti tik ,svetimžodžius ir kalbos netaisyklingumus“. Be to, jie pageidavo, „kad ị ši darbą būtų ịtraukti religingi ir tautiškai nusistatę, savo praeitị branginą ev. liuteronys lietuviai, ir kad tik taip paruoštas darbas būtų išleidžiamas. Kitaip šis svarbus darbas šiais rimtais laikais, kada minimas repatriacijos klausimas, neatneš tinkamus vaisius, giliai pažeisdamas tikybinę ir tautinę evangelikų liuteronių lietuvių dvasią“" (Jurbarko..., 1939, 1. 34).

Daug griežtesnio turinio skundą 1939 m. gruodžio 23 d. Ministrui Pirmininkui ịteikè 23 Tauragès parapijiečiai. Jame rašè:

„Pasklido evangelikų lietuvių visuomenę jaudinantys gandai, kad jai norima išleisti nevykusiai sugadintas giesmių knygas. Skaudu būna, jei kas griauna medžiagiškus tautos paminklus, bet dar skaudžiau, kada matome griaunamus ir žalojamus brangiausius mūsų tautos dvasinius paminklus. Tai tų darbų pradininkai būna arba pikti svetimieji arba nesąmoningi savos tautos vaikai.“

Laiško autoriai supažindino Ministrą Pirmininką su turtinga Mažosios Lietuvos Liuteronų bažnyčios giesmyno istorija, išsakẻ abejonių dẻl giesmy- 
no Redakcijos komisijos kompetencijos. Konsistorijos pastangas jie vadino „lietuviškumo ir liuteroniško tikejjimo“ griovimu:

„Ima išgąstis ir baimè, kaip galima leisti griauti pačius lietuviškumo ir tikybiškumo pamatus. Tik reikia atsiminti, kad lietuvių ev. tautinis atgimimas ir tėra pagrịstas tais dvasiniais turtais. Lietuviškosios giesmių knygos aiškiai pasako, kad jis ne tas pats, kaip vokietis ir kas svarbiausia, kad tai ne nuo šiandien, bet nuo pačių Liutieriaus laikų. Kokis gi reikalas verčia griauti šį seniausią lietuviškumo paminklą evangelikų bažnyčioj?“

Skundo autoriai Liuteronų bažnyčios vadovybei pažėė nemažai kritikos. Giesmyno projektą jie siejo su tautinio atgimimo Liuteronų bažnyčioje slopinimu. Jų manymu, šiuo projektu konsistorija pademonstravo abejingumą tautiniam sąmoningumui, parodé, kad ji ,tarnauja svetimiesiems“ - tiems, kurie siekia pakirsti lietuviškumo šaknis ir „susmukdyti lietuviškumo dvasią“ bažnyčioje.

„Bet matome, kad dabar Lietuvos ev. Bažnyčioj eina kova su svetimais atèjūnais, kurie trukdo prasidejusị atgimimą, nori tam atgimimui išplèšti pačius stipriausius istorinius pagrindus. Kaip galima bažnyčioj leisti griauti mūsų amžiais išsaugotus paminklus? Bet tai gerai suprantama, kodèl šie niekingi ir tautai žalingi darbai keliami vykdyti, o tik todèl, kad bažnytinejj dirvoj dar tebevyrauja svetimieji, nes veik išimtinai visi kunigai tebẻra svetimtaučiai, dar klebonijose eina agitacija priešinga mūsų tautos interesams. Štai tokių pastangų darbas ir yra sutraukyti mūsų gyvus ryšius su vakarų lietuviškumu, susmukdyti lietuviškają dvasią. Tokiai kunigijai esant negalima jai patikèti jokio didesnio lietuviškojo darbo. Šie mūsų Bažnyčios „,vadovai“ siekia toli gražu ne tikybinių tikslų. Jiems talkininkauja dèl pinigo, dèl garbès tuščios ir dèl kitų sumetimų nesąmoningi, pasimetę lietuviai, kurie neverti lietuvio vardo.“

Kritikai ironiškai tvirtino, kad giesmyno Techninejje ir Redakcijos komisijose pasigendą lietuvių kalbos bei poezijos ekspertų, tokių kaip Kristijonas Donelaitis, Liudvikas Rèza, Frydrichas Kuršaitis, kurie būtų verti plunksna prisiliesti prie senujų giesmių tekstų. Priešingai, giesmių tekstų redaktoriai èmèsi darbo neturédami nei tam būtinų gebejjimų, nei patirties: „Nei vieno mes nematome, kuris būtų pasižymėjęs mūsų lietuvių kalbos ar lietuvių li- 
teratūros poezijos darbe. Kaip tada pavadinti tokị neatsakingą lindimą ne ị savo reikalą ir visiškai nesulig savo išgalių.“ Ypač daug kritikos pažerta reformatų kun. A. Šernui. Neminèdami jo pavardès, laiško autoriai jo atžvilgiu taikè epitetus „meisteris“, „žodžiautojas“, o jo redaguotus tekstus lygino su „nuvalkiotais eilèraščiais“.

„Tų giesmių „meisteris“ yra ne daugiau, kaip žodžiautojas, be jokio gilesnio religinio jausmo, bet ir visiškai be jokios meno ir estetikos nuovokos. Jis imasi perdirbinèti senų gerai pažịstamų, atmintinai mokamų giesmių posmus, padaro iš jų tikrą karikatūrą, šventos, gilaus tikybinio jausmo pilnos giesmès ịgauna juokingo, nuvalkioto eilèraščio pobūdị. Šis eiliadaris ir geriausiose vietose iš skiemendario kevalo neišsirita.“

Siekdami parodyti kritikos pagrịstumą, skundo autoriai pateikè keletą giesmių ,subjaurojimo“ pavyzdžių.

„Jau vieną brangiausių lietuviams ev. giesmę: „Miela Kristaus galvelè “ išverte ị tokị dalyką: „O Galva kruvinoji“ (...) Kiekvienas ev. lietuvis dèl tokio taip brangios giesmès subjauriojimo jausis įžeistas. Toliau toj pačioj giesmèj:

„Kad gailiai apraudosiu, kai tau nutrūks jèga

Ir kad tave globosiu, kai tau nulinks galva“".

Ar tai nėra piktas religinio jausmo išdarkymas? „Lūpų raudonoji spalva" - tai tinka bet jau tik paties autoriaus skoniui, bet jau ne giesmiu knygoms...

Arba vèl kaip gražiai visiems pažistama giesmè Nr. 346 „Dabar tave paliksiu ak sviete piktasis“ šitaip išgadinta: „Jau aš tave paliksiu pasauli nešvarus.“

Juk, jeigu žmogus jau nebeskiria tokių sąvokų kaip ,piktas“ ir „nešvarus“, jeigu jam tai vis tasia ir vis labiau linksta ị nešvarumą ir juo verčiasi.

Štai III dalies giesmè Nr. 54, mūsų tikèjimo pagrindas, „Ponas Dievas mums pilis tvirta“ yra šitaip suniekinta: „Tvirčiausia prieglaudos pilis.“ Jau išmestas Dievo vardas, ar taip galima sauvaliauti? Ir vietoj to įdètas žodis ,prieglaudos“ ir tai visas jausmas išèjo ubagiškas ir perkreiptas... Matome, kad visas buvęs pakilus jausmas ir poetiškumas bei šventumas šioj giesmèj yra visiškai pražudytas. Toj pačioj giesmèj toliau prirašęs dar daugiau tuščių, beprasmiškų, neestetiškų, o jau toli gražu netikybiškų 
dalykų, pav.:

„Jèzus mūsų karvedys,

Gèda kas neišlaikys,

Negalès pasiekt laimikio“ ir t. t.

Visiems atmintinai žinoma giesmè dèl jos švelnaus tikybinio jausmo g. kn. Nr. 328. Antras jos posmelis taip skamba:

„Jau saulè nusileido...“

Iškreiptas šitaip:

„Saulute, kur tu dejais?

Ar nuplaukei su vejjais..."

Matome, koks sauvaliavimas ir kokie nesąmoningi žodžiai peršami pakaitui. Verčia tas dvieilis tiktai juoktis, būtų gerai, kad jis ir eitų juokų skyriun, bet ne ị mūsų giesmių knygas.

Yra daugelis giesmių, kurios taip sugadintos, kad jų visiškai atpažinti negalima, o pagiedoti netgi neįmanoma. Pavyzdžiui, tokia giesmè kaip: „Pranašai didis“, kuri visuomet būdavo giedama per iškilmingas Bažnytines ir Tautines šventes, kurią daug kartų yra giedoję didžiuliai suvestiniai visos Lietuvos chorai, dabar ji padaryta visiškai nepagiedama.“

Laiško autoriai ypač piktinosi naujo giesmyno bendrine lietuvių kalba, kurią jie vadino „gatvès kalba“. Jiems tai buvo tolygu senojo giesmyno tekstu „nusakralinimui“. Daugeli redakcinių sprendimų jie tiesiog vadino „brangaus bažnytinio ir tautinio meno žalojimu“, dèl ko kilo ,pasipiktinimas evangèliškoj lietuvių visuomenèj“. Jie dèkojo Respublikos Vyriausybei už giesmynui rengti skirtą paramą, bet apgailestavo, kad reikšminga Švietimo ministerijos parama panaudota ne „dvasiniams lobiams turtinti, bet juos skurdinti ir žaloti, nes tokiu giesmių, kurios mums dabar peršamos, nei vienas lietuvis ị rankas neims“.

Cituodami kalbininką Joną Jablonskị, laiško autoriai prašè Ministro Pirmininko apsaugoti oficialų liuteronų giesmyną nuo kalbinio suniokojimo: „Kalba yra visų mūsų didysis tautos, jos pačios pasistatytas paminklas. Patys mes, būdami tautos vaikai, savo motinos paminklo negriaukime. Tvorele ji aptverkime ir tiems, kur žemę knisa, jo teršti, griauti neleiskime“ (Tauragès..., 1939, 1. 9-10).

1939 m. gruodžio 27 d. švietimo ministras gavo dar vieną Jurbarko parapijiečių skundą. Gavėnių ir Kasiulaičių šeimų nariai rašè: „Mes, evangelikai lietuviai, pajutome, kad esame apiplěšiami, nes mums norima atimti bran- 
giausias mūsų turtas iš tèvų paveldètas, mūsų šventieji raštai. Mūsų giesmių knygos yra dideliame pavojuje. Jas kèsinasi sunaikinti ir sužaloti.“

Kaip ir tauragiškiai, jurbarkiečiai akcentavo turtingą liuteroniškų giesmių paveldą, jų iškilią kalbą, grožį, svarbą tikèjimui, vadino jas ,amžinuoju lobiu“, kuriuo lietuvininkai niekada nepaliaus didžiuotis. Ne veltui lietuviškų giesmių grožis traukte traukia kiekvieno lietuvio širdị, o nemažai tikinčiųju jas moka atmintinai. Šios giesmès išlaike liuteronų tautinę dvasią rusifikacijos laikotarpiu. Tada jos tapo lietuviško rašto pažinimo šaltiniu, o kai „žiauri letena perlabai prislègdavo, tai giesmès skambẻjo iš lūpu i lūpas, perduodamos buvo atmintinai, taigi giesmé galingai ir sékmingai kovojo, kad lietuvis evangelikas nenutaustų“. Be to, lietuvininkų giesmynas tapo dvasinès stiprybės šaltiniu liuteronams išeiviams Amerikoje. „Pagerintos giesmių knygos“ padejo lietuvininkams išlaikyti savo tautinę savimonę „tolimoje Prūsijoje“. Iš Kauno liuteronų bažnyčios transliuojant radijo pamaldas, pasièmę giesmynus lietuviai liuteronai sėsdavosi prie radijo imtuvų ir jas kartu giedodavo. „Ak gi kaip būtų tada“, - klausė jie, „kai šias mūsų giesmių knygas mums išplèš, kai tą brangų tautiškumo ir tikybiškumo ryši sutraukys, kai sudegins tuos tiltus, kuriais turi eiti mūsų tautiškasis atgimimas ir sąmonèjimas. Dẻl tokių piktų ketinimų ima mus didelis nerimas ir baimè. Juk mums tuo giesmių knygų sunaikinimu atima tą tvirčiausią pamatą tautinès savigarbos ir nepriklausomybès“.

Jurbarkiškiai piktinosi konsistorijos ketinimais „,sugriauti“ ši lietuvininkų dvasinès stiprybės šaltinị ir tikèjimo paminklą, pakeičiant iškilią ir dvasingą giesmių kalbą paprasčiausia „,gatvès kalba“, o kun. A. Šerno suredaguotus tekstus autoriai vadino pasityčiojimu iš lietuvininkų kalbos, pasibaisètinu jos niokojimu:

„Pirmiausia tą švelnią iškilmingą giesmių knygų kalbą nori pakeisti gatvès šnekamaja kalba, pilna kalbinių nesąmonių, visiškas kirčio nepaisymas, skiemenų skaičiaus nelygumas padaro daugeli giesmių visiškai nepagiedamomis. Maža to išdristama sauvaliauti pikčiausiu būdu: išniekinamos ir iškraipomos brangiausios mūsų giesmès, kad nei savote niekas nesisavos. Išmèto iš giesmių netik atskirus žodžius, bet ir ištisus sakinius, o net ir skirsnelius, kad iš 20 skirsnelių nelieka nei ketvirdalio.“ 
Skundo autoriai pateikè visą eilę „giesmių sudarkymo“ pavyzdžių:

„Visiems mielai pažįstama giesmė „Eikš su savo malone pas mus Jėzau Kristau“" ketvirtas šios giesmės skirsnelis pavirsta ị tokị juoką:

„Lik su mumis nes baigias šventųjų lūkesys,

Iš pamatų svyruoja pasaulio rutulys.“

Tokia mūsų šventa giesmė „Miela Kristaus galvelè“ iškreipiama pavirsta „O Galva kruvinoji“ - jau išmetamas „Kristaus“ vardas, matytis jau gèdisi to Vardo, gi žodis kruvinoji pas mus vartojamas kaipo vienos ligos pavadinimas. Toliau toj pačioj giesmèj taip išniekinamas Jėzaus vaizdas, kad pavaizduojamas Jèzus raudonomis lūpomis:

„Rausvų skruostų gražna

Ir lūpų raudonoji spalva...“

Kaip gi mes galètume tylèti, kada taip užgaunamas mūsų šventas jausmas, nerasime nei vieno evangèliko lietuvio, kuris su pasipiktinimu neprotestuotų prieš tokị šventų raštų išdarkymą... Čia matome kokius nešventus, nešvarius žodžius nori įdèti ị amžiais išlikusias gražias mūsų giesmių knygas. Dar toliau vienoj vietoj įdeda tokius neleistinus grynai doroviniu atžvilgiu žodžius: „Kai man gyslos suliepsnoja kūno kraujo geiduliais“ (...) na ar tai ne išgąstis ima. Kokia graži, kokia lietuviška giesmè yra „Kelkit karžygiai kovoti, sekit savo Viešpatį“ (...) Rodos, čia nieko nei kalbos, nei grožio atžvilgiu prikišti negalima, tai drąsos ir pasiaukojimo himnas, tačiau ir ši giesmė neišvengė piktų rankų, ir čia viskas iškreipta nepažistama. Prasideda ji taip: „Stokite kariai ị kovą", tai suubaginimas iškilmingos nuotaikos, pasidaro panašu ị paprastą puskarinkio komandą, o ne ị giesmès jausmą. Toliau pirmame tos giesmès skirsnely randame tokias eilutes:

„Jau laimėjo mūs galva,

Kas besnaudžia tam bèda.“

Juk tai yra nieko daugiau kaip neskoningas tuščiažodžiavimas, sudarkymas gražių, šventų giesmès žodžių, pavertimas jų į tuščią plepalą. Antras tos pačios giesmės skirsnelis mūsų knygose taip skamba:

„Paskui jam maldoms drąsiausiai.

Paskui - ar bijotųs kas?

Kristus yr laimejjimas...“

Taigi čia visi jaučiame, kokia didinga plaukia iš tų žodžių dvasia, kaip pagauna žmogaus nuotaiką, tarytum koks didingas šūkis ị pasiaukojimą, i pergalę, ị laimèjimą. O suniekinti tie žodžiai taip:

„Paskui jị maldoj, budynèj.

Jèzus mūsų karvedys

Gẻda, kas neišlaikys...“ 
Tokio eiliadirbio panaikinamas visas giesmès šventumas ir grožis, matyti neturèta to žmogaus jokio nusimanymo apie mūsų giesmių švelnumą ir grožị. Penktojo šios giesmès skirsnelio pradžia taip sudarkyta! „Negalès pasiekt laimikio“ (koks iškraipymas), o to skirsnelio pabaiga, kuri mūsų knygose taip skamba: „Tik per karą ir kovas tvirtas pakajus gaunamas“ paverčiamas ị: „Tik kova keliu drausmès įsigyjama garbès.“ Tai tegul pasako, ar tai nèra bjaurus pasityčiojimas iš mūsų tikejjimo iš lietuviškosios kalbos, ar tai nèra piktas sauvaliautojo siautimas mūsų kalbos ir tikejjimo brangenybėse? Jis kovą dèl taikos paverčia kova dèl garbès. Mes šaukiamès, Viešpatie, Tavo pagalbos ir tikime, kad toks niekingas darbas negalès įvykti. Toks pasibaisètinas niokojimas turès būti sutrukdytas. Čia juk nebuvo galimybès suminèti visas tas niekystes, kurios ten knibždète knibžda kiekvienoj eilutejj.“

Nurodydami ị kultūros paminklų apsaugos ịstatymus ir tautos kultūrinio paveldo išsaugojimą, laiško autoriai prašè švietimo ministro apginti nuo visiško suniokojimo ši „lietuvių kalbos ir liuteroniško dvasingumo paminklą،, neleisti atiduoti lietuvininkų dvasinių bei tautinių vertybių ,i piktujų rankas sunaikinimui“, o ,juk mūsų tos giesmių knygos tai ta pirmoji lietuviška knyga, kuri kaip koks dvasios karžygis išlaikè gyvenimo kovoj mums mūsų brangią, mielą tėvų lietuviškają kalbą, tai kas drịstų tą budelišką jų naikinimo darbą įvykdyti?"“ (Gavènių..., 1939, 1. 219-220).

Tauragiškių ir jurbarkiečių laiškai gana gerai atskleidè visų naujojo giesmyno oponentų argumentus bei perteikè jų kritikos esmę. Konsistorija suprato, kad susilauks protestų bandydama administracinėmis priemonemis įdiegti naujaji giesmyną parapijose. Taigi nusprendè laikytis kompromisinès nuostatos ir sutiko leisti pačioms parapijoms nuspręsti, iš kokio giesmyno giedoti.

$1941 \mathrm{~m}$. po liuteronų repatriacijos suformuota naujoji konsistorija pritare skundų autorių nuomonei. Tarp jos narių buvo kun. A. Baltris, kuris ryžosi geriau būti atleistas iš šventosios tarnystès nei išsižadèti naujojo giesmyno kritikos. Prisiminęs Kretingos parapijoje kilusį konfliktą, A. Baltris parašè: „Po to, kai su išvažiavusiaisiais išvažiavo ir vyriausieji naujo giesmyno (Šerno) iniciatoriai, dèl jo kilusieji neramumai pasišalino ir vèl yra taika, nes ir Kretingos ev. liut. parapijos lietuviškoji liaudis ištikimai laikosi prie savo senojo tėviškojo giesmyno, Giesmių Knygų“ (Kretingos..., 1943). Konsis- 
torijos sudėtyje buvo kun. Martynas Preikšaitis ir Mikas Preikšaitis - aktyvūs prieškario patriotinès liuteronų organizacijos „Pagalba“ nariai. Kone visi buvę „Pagalbos“ nariai giesmyno projektą laikè žalingu tautiškumo dvasiai bažnyčioje. Dèl radikalios tekstų redakcijos projektui nepritare ir jauniausias konsistorijos narys kun. Jonas Kalvanas. Nepaisant pirmininko E. Leijerio teigiamos nuomonès apie projektą, akivaizdu, kad paskutinès tarpukario konsistorijos parengtas giesmynas bažnyčioje neprigis.

\section{1942 m. „Evangelikų giesmynas su maldomis“}

Gavusi neigiamą konsistorijos atsakymą, Reformatų kolegija nusprendè vienašališkai publikuoti giesmyną. KaIšleido: Lietuvos Ev. Reformatu Kolegija ir Lietuvos Ev. Liuterioniu Konsistorija. dangi projektas buvo aktualus tik jai, ji kritiškai peržiūrèjo giesmyno rankraščius ir iš 500 liuteronų komisijos suredaguotu giesmių atrinko tik 388. Kolegija peržiūrèjo ir maldyną. İžanginiai „Tève mūsų“ maldos žodžiai pakeisti ì reformatų tradicijai būdingą „mūsų Tève“. Vietomis sukeistos liuteronų ir reformatų pamaldų tvarkos. Redaktoriai nusprendè knygoje nespausdinti Martyno Liuterio „Mažojo katekizmo“ ir reformatų „Heidelbergo katekizmo“ santraukos.

Kolegija tikejjosi, kad nepaisant šių pokyčių giesmynas išliks ekumeninis. $\underline{ }$

\section{Eoangelikn Giesmynas su maldomis}
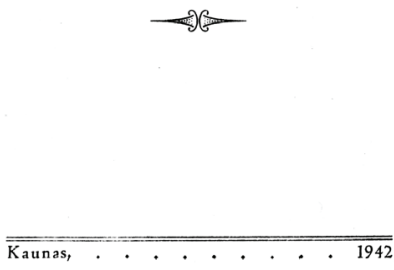

Ji kreipèsi ị konsistorijos reikalų vedèją A. Juozuvaiti, prašydama parašyti jam pratarmę, kur būtų atskleista glausta projekto istorija ir abiejų bažnyčių indèlis ị knygos rengimą. 1942 m. liepos 22 d. reformatų kun. Aleksandras Balčiauskas nusiuntė pratarmę konsistorijos pirmininkui E. Leijeriui. Laiško 
autorius minejjo, kad buvo parašytos dvi pratarmès: pirmojoje buvo gausu pavardžių ir datų, antroji - trumpesnè. Kolegija pritarè A. Juozuvaičio parengtai trumpesnei pratarmei (A. Balčiausko..., 1942).

E. Leijeris iš pradžių dvejojo, ar pritarti reformatų ketinimui pažymèti, kad knygos leidèja buvo ir Liuteronų bažnyčios konsistorija. Po mėnesio, rugpjūčio 28 d., ị ji kreipèsi A. Juozuvaitis, ragindamas pirmininką pritarti „Šerno giesmynui“ ir pratarmei (A. Juozuvaičio..., 1942a). E. Leijeris galiausiai sutiko, bet pratarmę šiek tiek pakoregavo: neliko informacijos, kad rankraštis prieš jị spausdinant buvo ịteiktas Lietuvos generalinio komisaro Theodoro Adriano von Rentelno peržiūrai ir knyga publikuojama Reicho valdžios sutikimu; išbraukè sakini, kad naujasis giesmynas visapusiškai pralenkia iki šiol buvusius liuteronų ir reformatų giesmynus (Giesmyno..., 1942), nes toks teiginys sukeltų nereikalingus liuteronų ginčus ir protestus.

1942 m. pabaigoje giesmynas atiduotas spaudai. Gruodžio 15 d. A. Juozuvaitis informavo E. Leijerị apie pirmų devynių knygos lankų atspausdinimą. Jo nuomone, jie atrode gana estetiškai. Vis dèlto senasis oficialaus liuteronu giesmyno formatas ir „rinkimo būdas“ jam pasirodè mielesni (A. Juozuvaičio..., 1942b).

Giesmynas atspausdintas 1943 m. pradžioje. Ivadas skelbè, kad knygą išleido Reformatų kolegija ir Liuteronų konsistorija. Iš dalies tai atitiko tikrovę, nes giesmyno projektą inicijavo ir spaudai parengè liuteronai. Reformatu vaidmuo, nepaisant A. Šerno indèlio, buvo minimalus. Kolegija pasirūpino tik knygos atspausdinimu. Giesmyno pratarmèje nepagrịstai tvirtinta, kad „giesmyną po 5 metų ịtempto darbo paruošè poetas kunigas Adomas Šernas“. Visas knygos parengimo nuopelnas priskirtas vienam asmeniui. Paskutinès tarpukario konsistorijos pirmininkas Kristupas Gudaitis savo atsiminimuose pastebejo, kad „kun. Šernas, kaip ir visi kiti prie to giesmyno paruošimo dirbusieji, skaitėsi tik to giesmyno ruošimo bendradarbiais“" (Gudaitis, 1957, p. 363). İžanga atskleidè buvusios Lietuvių evangelikų sajungos unionistinius ketinimus. Ji skelbè, kad knyga „turi tikslą jungti ev. reformatus ir ev. liuterionis vienybės ryšiais su Viešpačiu Dievu ir vienus su kitais“" (Evangelikų..., 1942, p. 5-6). 


\section{Liuteronų reakcija ị naujaji giesmyną}

1943 m. pavasarị A. Juozuvaitis išsiuntė dedikuotus giesmyno egzempliorius Lietuvos bažnyčios ir repatrijavusiems kunigams. Jų reakcija ị naują giesmyną buvo skirtinga.

Knygą palankiai vertino repatrijavęs kun. Vilius Gaigalaitis. 1943 m. gegužès 26 d. laiške E. Leijeriui jis rašè: „Tai [giesmynas] man rodosi, yra tikra Dievo dovana šituose tamsiuose laikuose. Rodosi ir gerai pritaikinta taipgi liuteronims, taip kad visi galès juomi tinkamai pasinaudoti. Tai man džiaugsmas“"(V. Gaigalaičio..., 1943).

Kitaip ì knygą žvelgé Lietuvos kunigai. Ypač kritiškai apie giesmyną atsiliepe kun. A. Baltris. Jis pasijuto asmeniškai užgautas pratarmèje išvydęs įrašą, kad knygos leidimui pritarè liuteronų konsistorija. Panašiai knygą vertino ir kun. J. Kalvanas. 1943 m. gegužès 10 d. laiške E. Leijeriui jis klause, kuo remiantis tarp giesmyno leidejų paminèta konsistorija, kai ji pati projekto atsisakè. J. Kalvanas buvo i̊sitikinęs, kad toks įrašas sukels tik nereikalingus ginčus ir nesutarimus.

„Stebina tik antroje vietoje lyg iš malonès baimingai pakištas prierašas: „Ir Lietuvos ev. liut. Konsistorija." Juk mes Kaune poseddyje buvome nutarę šitos malonès atsisakyti, kas buvo ir užprotokoluota. Kodėl nebuvo šio nutarimo laikytasi? Juk ev. liut. bažnyčia visame pasaulyje laikosi lygiateisiu demokratiniu principu, kur atsižvelgiama ị daugumos nuomonę ir norą. Ar vertėjo kelti senąsias dulkes viešumon? Prasidès vẻl ginčai, nesutikimai. Kun. A. Baltris jau pradeda ta kryptimi veikti. Gavau iš jo ilgą laišką, kuriame jis jaučiasi iki ašarų užsigavęs ir nusivylęs. Ir iš tiesos, jei jis ir gavo giesmyno egzempliorių su įrašu apie talkininkavimą jo išleidimui - juk jis 
iš idejos, tradicijos ir širdies buvo prieš ji - tai visai teisingai galëjo suprasti kaip pasityčiojimą iš jo nuomonès ir švento įsitikinimo. Pasirodo mes jau keli belikę tarp savęs nesutariame ir ką nutariame nesilaikome, o ir bažnyčioje būtina drausmè ir vienybè" (J. Kalvano..., 1943a).

Kun. J. Kalvanas ị giesmyną žvelgè pragmatiškai, manydamas, kad knyga gali būti naudojama karo metu atsikūrusiose parapijose, nes jos ,neturi dar tradicijos bei nepažịsta kalbiniai ir literariniai brangaus lietuvių literatūros inašo Mažosios Lietuvos giesmių knygų ir nèra prie jų pripratusios“. Tarp tokių buvo 1941 m. sovietų okupacijos metu bažnyčios netekusi Kauno parapija, kuri dar tarpukariu skundèsi, kad senasis lietuvininkų giesmynas dèl kalbos archajiškumo jos netenkino. J. Kalvanas siūlè leisti giesmynu naudotis Kauno ir Telšiu parapijoms: „Ten jis ras iejjimą ir prigis, bet nè vienoje senųjų lietuviškujų parapijų.“

Kiek atviriau savo nuomonę apie giesmyną jis išsakè 1943 m. gegužès 12 d. laiške A. Juozuvaičiui. Karo metu atspausdinta knyga jam atrodè, nors ir kukliai, bet padoriai. Vis dèlto jis ją vertino ne daugiau kaip tik ,ịnašą i evangelišką literatūrą“, nes giesmynas buvo „vieno asmens kūryba, kuriame atsispindi tik jo religinis ir poetinis veidas“.

„Visoje Bažnyčios istorijoje, išskyrus negausią Lietuvos Reformatų šeimą, nežinomas yra atsitikimas, kad visai bažnyčiai parašytų giesmyną vienas asmuo. To neįstengia né poetas genijus, nekalbant jau apie šiaip prasiprususius eilèkalius. Tai neịmanoma“ (J. Kalvano..., 1943b).

Kun. J. Kalvanas tvirtino, kad knyga jokiu būdu negali tapti oficialiu Liuteronų bažnyčios giesmynu. Ji tinka tik , asmeniškam naudojimui, lygiai kaip Maironio, Vinco Mykolaičio-Putino ar kito asmens kūryba“. Ypač kritiškai jis vertino „racionalistinį“ A. Šerno giesmių redagavimo stilių. Jo manymu, dèl to nukentejjo tekstų poetinè vertè, giesmès neteko savo dvasinio grožio, nebesukelia gilių religinių jausmų:

„Šernas yra racionalistas, moralistas. Jam trūksta gilaus religinio pergyvenimo. Jis rašydamas yra žvelgęs tik ị kalbą, ritmą, skiemenų skaičių, gramatinị ir muzikos kirtị ir, prisilaikydamas šių dèsnių, šaltai, kaip amatininkas, yra kalęs savo eiles. Todèl jo eilèdara gali patenkinti kalbinị skonị, bet negali iššaukti religinio pergyvenimo, gilaus jausmo. Šitą giesmy- 
ną ịvesti oficialiu visos Lietuvos evang. Bažnyčios giesmynu būtų tiktai ,atestatio paupertalis“ (biednystès pažymèjimas). Tuo tarpu mes nesame tiek biedni. Senosios giesmių knygos slepia savyje seną evangelišką tradiciją ir daugel tikros religinès poezijos perlų. Tai yra didelis kultūrinis, istorinis, kalbinis ir religinis paminklas, kurio vertę kartais katalikai-kalbininkai labiau supranta negu evangelikai. Čia mūsų tragedija. Nenorèkime, kad kitatikiai ir kitataučiai iškeltų jo vertybę, kaip tai buvo padaryta su lietuviškaja tautosaka - liaudies dainomis! Žinoma, senasis giesmynas taisytinas, bet jokiu būdu neatmestinas. Tuo būtų parodyta mūsų nesugebejjimas senovès ịvertinti ir senujų tradicijų, kuriose glūdi jèga, niekinimas“"(J. Kalvano..., 1943b).

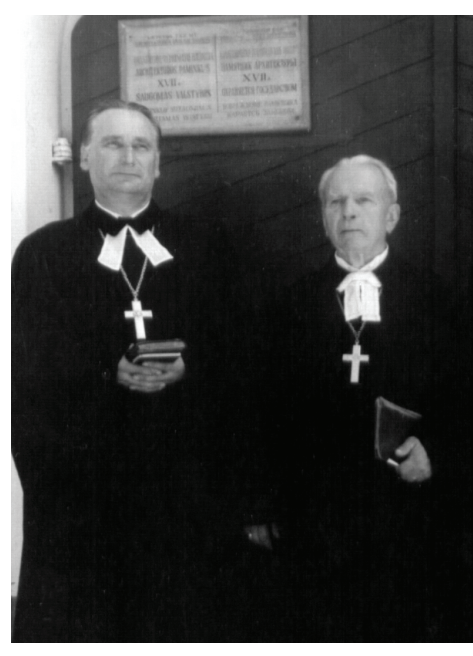

Liuteronų bažnyčios vyskupas J. Kalvanas ir Reformatų bažnyčios superintendentas A. Šernas prie Papilio reformatų bažnyčios, $1960 \mathrm{~m}$. rugpjūčio $28 \mathrm{~d}$. JKA

Kun. J. Kalvanas pakartojo, kad knyga gali būti pradèta naudoti tik karo metu atsikūrusiose parapijose, tačiau jis jokiu būdu nesutiks, kad naujasis giesmynas ,išmestų arba pakeistų senaji giesmyną, kurio religinè, istorinè ir poezinè vertė nepalyginamai aukštesnè už naujajị ‘.

A. Juozuvaitis giesmyną vertino palankiau. 1943 m. gegužès 17 d. laiške E. Leijeriui jis iš dalies sutiko su J. Kalvano pastabomis, bet nepritare jo nuomonei, esą kun. A. Šernas laikytinas giesmyno autoriumi. „Giesmynas nėra kun. Šerno parašytas, bet yra jo išverstas iš originalo.“ Jis priminè, kad ,niekas oficialiai ir nemanė giesmyną ịvesti parapijoms, o šis reikalas turi ịvykti savaime, gyvenimui diktuojant". Knyga palankiai sutikta jo pažistamų Kaune ir net tarp Romos kataliku, o vienas šios konfesijos rašytojas pareiškè, kad jie patys dar neturi giesmyno, parašyto tokia gražia kalba. „Kad giesmynas išejo, tai tik reikia džiaugtis“, - samprotavo A. Juozuvaitis, - ,, jeigu mūsų kunigai norètų jị ignoruoti, tai bus galima 
paleisti ị knygynus, ir jis bus kitatikių bei laisvamanių išpirktas“ (A. Juozuvaičio..., 1943). A. Juozuvaitis paprašè, kad kun. E. Leijeris, kaip konsistorijos pirmininkas, pats teiktųsi atsakyti ị J. Kalvano kritines pastabas.

1943 m. gegužès 23 d. E. Leijerio atsakas J. Kalvanui buvo trumpas: „Dèl giesmyno išleidimo pasilieku prie savo ankstyvesnès nuomonès, kad jis šalia senojo giesmyno buvo būtinai reikalingas, ypatingai intelegentijai ir priaugančiai kartai“" (E. Leijerio..., 1943).

Giesmyno naudojimo parapijose klausimas 1943 m. rugsèjo 15 d. svarstytas konsistorijoje. Po ilgų ir emocingų diskusijų jos nariai nutarè, kad giesmynu galès naudotis Kauno ir kitos po sovietinès okupacijos bei repatriacijos atsikuriančios parapijos. Kiti bažnyčios nariai knygą galès įsigyti „kaip bažnytinę literatūrą". Posėdžio sekretorius A. Juozuvaitis nelabai tiksliai užrašè konsistorijos sprendimą. Pastaroji nusprendè nenaudoti giesmyno kitose parapijose, bet A. Juozuvaitis protokolų knygoje atsargiai įrašè „dar neįvesti““. Tai sukèlè kun. A. Baltrio nepasitenkinimą. Protestuodamas protokole jis paliko savo įrašą: „Už ketvirtą eilutę „dar neįvesti“ aš nebalsavau. Balsuojama buvo už neịvesti - nes aš tai taip pasiūliau, ir tas taip buvo priimta. Todèl tą „dar“ iš protokolo reikia išbraukti“ (Lietuvos..., 1943).

1943 m. gruodžio 2 d. A. Baltris laiške E. Leijeriui naujaji giesmyną vadino „Šerno giesmynu“ ir reikalavo kitame posėdyje pakoreguoti protokole ịsivèlusius netikslumus. Jis paneigè izžangos teiginį, esą knygą kartu su reformatų kolegija išleido ir liuteronų konsistorija. A. Baltris emocingai citavo kiekvieną konsistorijos protokolo sakinị ir net žodį. Ką reiškia žodelis dar sakinyje „parapijose dar neįvesti?“ - klause jis E. Leijerio. „Šitai tas reiškia, jog kas ị parapijas neịlenda per „dar neịvesti“, ịlenda ị jas per „rekomenduoti ịsigyti kaipo bažnytinę literatūrą". Gudriai suformuluota! Bet kaip nebuvo pasiūlyta ir priimta tas žodis „dar“, taip ir ne[buvo] tas „rekomenduoti“, bet tik buvo sakyta, kad ,gali“ ịsigyti. Rekomenduoti reiškia kunigams įsakymas iš sakyklų tai skelbti, o „gali“ reiškia, kaip sau nori“ (A. Baltrio..., 1943).

Giesmynas naudotas tik Kauno parapijoje. Liuteronų bažnyčiai skirtas tiražas sandẻliuotas jos bažnyčioje. Visos knygos pražuvo 1946 m. pavasarị išsiliejus Nemunui. Kun. Jonas Mizaras tvirtino, kad potvynio būta tokio didelio, jog buvo išgriauta net metalinè bažnyčios tvora (J. Mizaro..., 1946). 


\section{Nauja konsistorijos iniciatyva redaguoti „Pagerintas giesmių knygas“6}

„Ekumeninio“ giesmyno atspausdinimas paskatino liuteronų kunigus imtis naujos „Pagerintos giesmių knygų“ redakcijos. Apie tokį ketinimą kun. J. Kalvanas užsiminè 1943 m. gegužès 10 d. laiške E. Leijeriui. Tada jis manè, kad giesmyno parengimo darbą reikètų pradèti karui pasibaigus. „Po šio karo, jei sąlygos leis, žinoma, reiks tęsti senojo giesmyno tradiciją toliau ir aprengti jị kiek naujesniu rūbu“ (J. Kalvano..., 1943a). Šią mintị pakartojo ir A. Juozuvaičiui. „Tai, jei Dievas duos ir gyvensime, bus pokarinis darbas“ (J. Kalvano..., 1943b). Vis dèlto 1943 m. vasarą kunigų susitikime Kretingoje jis ir kiti dvasininkai nusprende nedelsiant imtis giesmyno redakcijos (J. Kalvano..., 1943c).

Kunigai nustatė giesmių redagavimo kriterijus. Giesmès „turi būti taisomos, pasilaikant kiek galint senaji jų veidą, išmetant barbarizmus ir tinkamai pakeičiant nepoetingos, neaiškaus ir nelietuviško stiliaus vietas, neaiškius posmelius palyginant su tų giesmių originalais“. Slavizmai turejjo būti šalinami, tačiau ,isisipilietinę barbarizmai, kaip bažnyčia, dūšia, pekla, svietas, bėda, ponas, griekas (...) paliktini““. Turèjo būti šalinami ir kalbos archaizmai: „Tariamosios nuosakos galūnès „bim“, vietininkai su „ausp“, „ump“, „iep“, „op“ ir kita“. A. Baltris ir kiti sakytojai reikalavo, kad būtų paliktos senajame giesmyne įprastos mažybinès žodžių formos, bet visi nutare, kad „mažybinès formos žodžiuose Kristus, Jėzus, Dievas, Viešpatis, Ponas“ nevartotinos. Visi sutiko, kad labai ilgos giesmès turi būti trumpinamos, paliekant ne daugiau kaip 15 posmų. Reikètų vengti dèl ritmo atsiradusių nevykusių sutrumpinimų ar pailginimų, tokių kaip ,yr, žyd, gers, išmikliudyk, karlystė, ang'lai ir t. t.“. Žodžio kirtis turi derèti su melodijos kirčiu. Trys „Pagerintų giesmių knygų“ dalys turi būti sujungtos ị vieną. Giesmyną reikètų papildyti naujomis poetiniu ir religiniu požiūriu vertingomis giesmemis iš populiarių liuteroniškų giesmynų, tokių kaip „Visokios naujos giesmès“, arba „Evangeliški psalmai“, „Ziono varpelis“, „Kelionès arpa“ ir kt. Tarp šalintinų giesmių buvo tos, kurių ,poetinè ir religinè verte menka (neturi rimo, yra grynai didaktiško pobūdžio be religinio pergyvenimo, mažai tebegiedamos, nebežinomos melodijos ir t. t.); giesmès, kurios neatitinka dabarties sąlygų (apie ciesoriuskaralius, popiežių, turkus, marą ir t. t.); giesmès šventėms, kurios evangelikų 
nebevartojamos, kaip Marijos ir angelų dienos; viena giesmè iš tų, kurios kartojasi du kartus“. Šalintinų giesmių aptikta 215 iš 696. Iki tol oficialusis giesmynas spausdintas gotikiniu šriftu, bet dvasininkai nusprendè, kad dalis tiražo turètų būti publikuota ir lotyniškomis raidėmis. Knygoje turejjo būti atspausdinta liturgija, maldynas ir katekizmo pagrindai. Kunigai nutare perskaityti suredaguotas giesmes ir aptarti giesmyno išleidimo klausimus Pjūties padèkos šventės metu Taurageje, $1943 \mathrm{~m}$. spalio $3 \mathrm{~d}^{2}$

Rugpjūčio 4 d. J. Kalvanas supažindino kun. Martyną Preikšaitị su Kretingos posėdžio nutarimais ir jam patikèta užduotimi. Redaguojant giesmes reikejjo atkreipti dėmesi ị posmų rimavimą, kalbos ir eilèdaros taisykles, kurių taip uoliai laikèsi kun. A. Šernas. „Juk ir Šerno eilèdaroje poezijos kaip ir nèra, bet už tat yra gana dailus suritmavimas, žodžių sudèstymas, eiliavimas, kurio jis pasiekè ilgai žodžius įvairiai nustatinèti bandydamas. Žinoma, čia reikia ne tiek sugebejjimo, kiek kantrybès.“ Knyga turèjo būti atspausdinta „iki 1947 m., kada bus minima Martyno Mažvydo, lietuviškos literatūros tèvo ir pradininko, pirmosios lietuvių kalba išleistos knygos 400 metų sukaktis“" (J. Kalvano..., 1943c).

1943 m. rugsèjo 15 d. „Pagerintų giesmių knygų“ redagavimo klausimas svarstytas konsistorijoje, kuri patvirtino sudarytą giesmyno rengimo komisiją ir įsipareigojo visokeriopai remti jos darbus (Lietuvos..>, 1943). Redaktoriai neįstengè laikytis nustatytų terminų, todèl giesmių redagavimo procesas vèl aptartas 1943 m. spalio 24 d. Tauragèje, Biblijos šventės metu³.

Redakcijos komisijos užmojai per tokị trumpą laiką parengti giesmyną spaudai buvo pernelyg optimistiški. Skyrèsi komisijos narių poetiniai gebejjimai, kalbos ir eilėdaros taisyklių žinios, ypač požiūris ị senojo giesmyno kalbą. Kun. A. Baltriui „Pagerintų giesmių knygų“ kalba, išskyrus kai kuriuos archaizmus, buvo priimtina. Kun. J. Kalvanas pageidavo, kad giesmès būtų redaguojamos pagal bendrinès kalbos taisykles.

2 Kun. A. Baltriui pavesta suredaguoti pirmos ir antros dalių giesmes Nr. 1-130, trečios dalies - Nr. 1-30; kun. Jurgiui Gavėniui - Nr. 131-244 ir Nr. 31-60; kun. J. Kalvanui - Nr. 245-348 ir Nr. 61-90; kun. M. Preikšaičiui - Nr. 349-500 ir Nr. 91-120, konsistorijos nariui Mikui Preikšaičiui - Nr. 501-542 ir Nr. 121-154 (Giesmių..., 1943).

3 Kun. A. Baltrio redaguojamos giesmès Nr. 1-100, kun. M. Preikšaičio - Nr. 100-200, kun. J. Kalvano Nr. - 200-300, kun. J. Gavėnio - Nr. 300-400 (Kunigų..., 1943). 
Nèra žinoma, kiek giesmių komisijai pavyko suredaguoti iki 1944 m. vasarą atsinaujinusių karo veiksmų. Naujoji šalies okupacija, antireliginė sovietinès valdžios politika, tikinčiųjų ir kunigų represijos, bažnyčios gyvenimo varžymas administracinėmis priemonėmis, giesmių redagavimo darbą darè nebeįmanomą. Tik 1970 m. sinode bažnyčia grịžo prie naujo giesmyno rengimo klausimo.

\section{Giesmyno naudojimas reformatų parapijose}

$\mathrm{Ne}$ mažiau sudetingas procesas buvo giesmyną ịdiegti reformatų parapijose. Iki tol reformatų tikintieji giedojo iš "Dagilio giesmyno“: „Giesmynas su maldų priedu Lietuvos evangel.-reformatų parapijų vartojimui“" kurị reformatų sinodo pavedimu $1910 \mathrm{~m}$. parengè mokytojas Stanislovas Dagilis (Gudaitis, 1957, p. 297). Giesmynas perspausdintas 1913, 1915, 1917, 1921 m. Refor-

\section{GIESMYNAS} su maldụ priedu

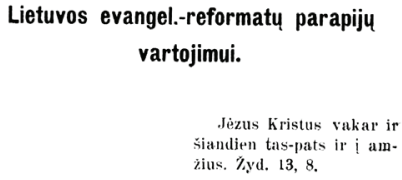
vartojimui.

Jezus hristus vakar ir siandien tas-pats ir i amzius, 7yd. 13, 8 .

(2) matų konsistorija ${ }^{4}$ nesiryžo paskelbti populiaraus „Dagilio“ giesmyno nebenaudotinu. Knyga parapijose turejjo būti pradèta naudoti laipsniškai. $1957 \mathrm{~m}$. sinodo metu planuota giedoti iš tradicinio ir naujojo giesmyno, lygiagrečiai paskelbiant abiejų knygu giesmių numerius (Ev. reformatų..., 1957, 1. 31). Giesmyno tiražas nenurodytas. Žinoma tik tiek, kad 1955 m. reformatų konsistorija vis dar disponavo daugiau nei tūkstančiu egzempliorių (A. Šerno..., 1955). Ipprastu viršeliu ịrišta knyga kainavo 25-30 rb., odiniu vir-

$4 \quad$ Sovietmečiu reformatų kolegija pervadinta ị konsistoriją. 
šeliu - 50 rb. 1958 m. konsistorija nupirko iš kun. A. Šerno 200 egz. odiniu viršeliu (Reformatų..., 1948, 1957, 1958, 1. 6, 39, 54), tačiau nèra žinių, ar naujasis giesmynas apskritai buvo naudojamas kurioje nors reformatų parapijoje.

Situaciją komplikavo Reformatų bažnyčią sukrètusi superintendento A. Šerno apostazè. Apie norą nutraukti ryšius su bažnyčia religijų reikalų igaliotiniui Justui Rugieniui kunigas slapta pareiškè dar 1961 m. (Igaliotinio..., 1961, 1. 39), bet viešai spaudoje savo ateistines pažiūras jis deklaravo tik 1964 m. vasarą. Prieš paskelbdamas savo garsujj pareiškimą „Kodèl aš darau tokị žingsnị““ (Tiesa, 1964-08-16), A. Šernas siekè parduoti likusius giesmyno egzempliorius. $1963 \mathrm{~m}$. rugsėjo 5 d. laiške kun. J. Kalvanui jis minèjo apie Biržų bažnyčios zakristijoje ,gulinčius“ jam priklausančius 120 giesmyno egzempliorių ir siūlè ,už prieinamą kainą visus parsigabenti savo bendruomenėms“. Spalio 14 d. kun. J. Kalvanas superintendentui atsakè, kad giesmynas naudotas tik Kauno parapijoje, todèl liuteronų bažnyčiai knyga nebuvo aktuali. Jei trūksta vietos Biržų reformatų bažnyčios zakristijoje, egzempliorius galètų paimti saugoti Biržų liuteronų parapijos nariai, tarp kurių galbūt atsiras tų, kurie norès įsigyti knygą asmeniniam naudojimui (A. Šerno..., 1963; J. Kalvano..., 1963).

Bažnyčios vadovo apostazė labai apsunkino sudètingą giesmyno diegimo parapijose procesą. A. Šernas buvo įvardytas knygos sudarytoju, todèl parapijiečiai i „Šerno giesmyną“ èmé žvelgti neigiamai. Jei knyga ir naudota kurioje nors parapijoje, po $1964 \mathrm{~m}$. apostazès reformatai giedojo tik iš „Dagilio giesmyno“.

1983 m. reformatų parapijas pradèjęs aptarnauti kun. Reincholdas Moras paliudijo, kad tuo metu reformatai giedojo tik iš „Dagilio giesmyno“. Biržu bažnyčios zakristijoje jis aptiko likusi $1942 \mathrm{~m}$. giesmyno tiražą, todèl baigiant susidèvèti oficialaus giesmyno egzemplioriams, parapijų taryboms pritarus, 1986 m. „Evangeliku giesmynas su maldomis“ visuotiniam giedojimui pradètas naudoti visose evangelikų reformatų parapijose. ${ }^{5}$ Nuo tada knyga tapo oficialiu Reformatų bažnyčios giesmynu. $2001 \mathrm{~m}$. perspausdintas fotografuotinis jos leidimas, iš kurio Lietuvos evangelikai reformatai gieda ir šiandien.

$52011 \mathrm{~m}$. gruodžio $12 \mathrm{~d}$. kun. R. Moro interviu. 


\section{7. „Evangelikų giesmyno“ ịtaka vẻlesniems liuteronų giesmynams}

„Evangelikų giesmynas“ gana pozityviai sutiktas išeivijos liuteronų bažnyčioje. Rengdami pirmaji lietuvių išeivijos evangelikų giesmyną, repatrijavę kunigai naudojosi jo giesmių redakcijomis. 1947 m. Kaselyje-Matenberge, Vokietijoje, publikuotame

\author{
MALDŲ IR GIESMIŲ
} KNYGELE்

„Evangelikų giesmyne su maldomis“ 200 giesmių paimta iš $1942 \mathrm{~m}$. knygos (Evangelikų..., 1947, p. 3). 1957 m. knyga papildyta naujomis giesmèmis.

Nikitos Chruščiovo valdymo laikotarpio pradžioje sušvelnèjus religinès spaudos varžymams, liuteronų konsistorija 1956 m. išleido nedidelès apimties „Maldų ir giesmių knygelę“, kur dalis giesmių perspausdinta iš 1942 m. giesmyno. Jos įvade konsistorija pabrèžè, kad šis kuklus leidinys

1956 m. „Maldų ir giesmių knygelë“, kur dalis giesmių perspausdinta iš $1942 \mathrm{~m}$. giesmyno nepretenduoja pakeisti senujų lietuvininkų giesmių knygų, „,bet nori joms tik patalkininkauti, būti mūsų konfesijos gyvenimo keliu einančiam žmogui portatyviniu vadovu - vade mercum. Apsišvietusiems lietuviams, kurie nori Dievą garbinti gryna savo tautos kalba, vengiant svetimybių ir kalbos žalojimų, knygelè nori patarnauti ịvairiais gyvenimo, o ypač atskirų kulto apeigų atvejais“" (Maldų..., 1956, p. 3-4). Knygelè platinta parapijose tikinčiujų asmeniniam naudojimui.

1970 m. sinodas nusprendè parengti naują giesmyno laidą, ją „stengiantis daugiau suderinti su tikinčiųų pamėgtomis 1936 m. Klaipėdoje išleistomis „Pagerintomis giesmių knygomis“(II-jo..., 1970, 1. 92-93). Konsistorija giesmyną atspausdino 1982 m. Knygos turinys rodo, kad 1942 m. ir 1956 m. giesmynai jai beveik neturèjo įtakos. 
$1942 \mathrm{~m}$. giesmynas padarė netiesiogini poveiki 1990-2007 m. rengiant naują Lietuvos liuteronų bažnyčios giesmyną (Krikščioniškos giesmès, 2007 m.). Jo Redakcijos komisija naudojosi išeivijos liuteronų publikuotais giesmių tekstais, kurių dalis paimta iš $1942 \mathrm{~m}$. knygos.

\section{Išvados}

Po 1941 m. repatriacijos sudaryta nauja Lietuvos Liuteronų bažnyčios konsistorija pasitraukè iš jos pirmtakès inicijuoto giesmyno projekto. Naujos bažnyčios vadovybės nuomone, giesmių tekstai redaguoti per daug radikaliai. 1942 m. Evangelikų reformatų kolegijos iniciatyva publikuotas „Evangelikų giesmynas su maldomis“ išimties tvarka pradètas naudoti Kauno parapijoje.

„Ekumenine““ knyga paskatino liuteronų konsistoriją sudaryti naują giesmyno Redakcijos komisiją, kurią ji ịpareigojo redaguoti tradicinio giesmyno tekstus kuo labiau laikantis jų originalo. Komisijos darbą nutraukè antroji sovietinè okupacija.

Giesmyno diegimą reformatu parapijose komplikavo superintendento A. Šerno apostazè. Tik susidèvejus oficialaus „Dagilio giesmyno“ egzemplioriams, 1986 m. knyga tapo oficialiuoju šios bažnyčios giesmynu.

1942 m. giesmynu naudojosi išeivijos Liuteronų bažnyčia, rengdama 1947 ir 1957 m. giesmynus. Lietuvos liuteronų bažnyčios himnologijai knyga darè netiesioginę ịtaką. Dalis jos giesmių sovietmečiu perspausdintos „Maldų ir giesmių knygelèje“ (1956 m.). Kai kurios 1942 m. knygos giesmès atspausdintos $2007 \mathrm{~m}$. Liuteronų bažnyčios giesmyne. Redakcijos komisija jas paėmè iš $1957 \mathrm{~m}$. išeivijos liuteronų giesmyno.

\section{Literatūra}

II-jo pokarinio visuotinio sinodo, ịvykusio Tauragės Martynos Mažvydo bažnyčioje 1970 m. rugpjūčio 23 d., protokolas. (1970). Lietuvos evangeliku liuteronu bažnyčios konsistorijos protokolu knyga 1955-1990. Konsistorijos archyvas.

A. Balčiausko laiškas E. Leijeriui, 1942 m. liepos 28 d. (1942). Pasiųstų raštų nuorašai 1941-1943. Jono Kalvano archyvas (puslapiai nenumeruoti).

A. Baltrio laiškas E. Leijeriui, 1943 m. gruodžio 2 d. (1943). Gauti raštai 1941-1944. Jono Kalvano archyvas (puslapiai nenumeruoti). 
A. Juozuvaičio laiškas E. Leijeriui, 1942 m. rugpjūčio 28 d. (1942a). Pasiustu rašttu nuorašai 1941-1943. Jono Kalvano archyvas (puslapiai nenumeruoti).

A. Juozuvaičio laiškas E. Leiejeriui, 1942 m. gruodžio 15 d. (1942b). Pasiustu rašttu nuorašai 1941-1943. Jono Kalvano archyvas (puslapiai nenumeruoti).

A. Juozuvaičio laiškas E. Leijeriui, 1943 m. gegužès 17 d. (1943). Gauti raštai 19411944. Jono Kalvano archyvas (puslapiai nenumeruoti).

A. Šerno laiškas J. Kalvanui, 1955 m. gruodžio 23 d. (1955). Konsistorijos 1956 m. susirašinejimas. Jono Kalvano archyvas (puslapiai nenumeruoti).

A. Šerno laiškas J. Kalvanui, 1963 m. rugsėjo 9 d. (1963). Laiškai 1959. Jono Kalvano archyvas (puslapiai nenumeruoti).

E. Leijerio laiškas J. Kalvanui, 1943 m. gegužès 23 d. (1943). Gauti raštai 19411944. Jono Kalvano archyvas (puslapiai nenumeruoti).

Ev. reformatų konsistorijos posėdžio protokolas, 1957 m. liepos 18 d. (1957). Lietuvos ev. reformatu konsistorijos posédžiu protokolu knyga 1946-1995. Konsistorijos archyvas (kopija).

Evangeliku giesmynas su maldomis. (1942). Kaunas: Kauen-Wilnaer Verlags-u. Druckerei. Evangeliku giesmynas su maldomis. (1947). I ir II dalis. Kassel-Mattenberg: Hof- und Waisenhaus-Buchdruckerei.

Gaigalaitis, V. (1998). Atsiminimai. Klaipèda: Klaipèdos universiteto leidykla.

Gaveniu ir Kasiulaičį šeimu skundas švietimo ministrui. (1939). LCVA f. 391, a. 4, b. 757.

Giesmynas su maldu priedu Lietuvos evangel.-reformatu parapiju vartojimui. (1915). Biržai: M. Yčo spaustuvè.

Giesmyno pratarmès projektas. (1942). Pasiųstu raštu nuorašai 1941-1943. Jono Kalvano archyvas (puslapiai nenumeruoti).

Giesmiu knygoms taisyti principai. (1943). A. Baltrio juodraščiai. Konsistorijos archyvas (puslapiai nenumeruoti).

Gudaitis, K. (1957). Lietuviai evangelikai. Hamilton: Rūta.

Igaliotinio J. Rugienio ataskaita Religiju reikalu tarybai už 1961 m. (1961). LCVA f. R-181, a. 3, b. 61.

J. Kalvano laiškas A. Juozuvaičiui, 1943 m. gegužès 12 d. (1943 b). Gauti raštai 1941-1944. Jono Kalvano archyvas (puslapiai nenumeruoti).

J. Kalvano laiškas A. Šernui, 1963 m. spalio 14 d. (1963). Laiškai 1959. Jono Kalvano archyvas (puslapiai nenumeruoti).

J. Kalvano laiškas E. Leijeriui, 1943 m. gegužès 10 d. (1943a). Gauti raštai 19411944. Jono Kalvano archyvas (puslapiai nenumeruoti).

J. Kalvano laiškas Martynui Preikšaičiui, 1943 m. rugpjūčio 4 d. (1943c). Gauti raštai 1941-1944. Jono Kalvano archyvas (puslapiai nenumeruoti).

J. Mizaro laiškas E. Leijeriui, 1946 m. gegužès 9 d. (1946). Gauti raštai 1941-1944. Jono Kalvano archyvas (puslapiai nenumeruoti). 
Juozuvaitis, A. (1939). Ar numatytame išleisti naujame lietuviškame evangeliškame giesmyne giesmių vertimas yra geras? Lietuvos evangeliku kelias, Nr. 25-26 (216-217), p. 104.

Jurbarko parapijiečių skundas švietimo ministrui. (1939). LCVA f. 391, a. 4, b. 761.

Kretingos ev. liut. parapija. santrauka veikimo nuo 1941.III.5 iki 1943.IX.30. (1943). Gauti raštai 1941-1944. Jono Kalvano archyvas (puslapiai nenumeruoti).

Kunigų suvažiavimo Tauragèje protokolas, 1943 m. spalio 24 d. (1943). Gauti raštai 1941-1944. Jono Kalvano archyvas (puslapiai nenumeruoti).

Lietuvos Evangelikų Liuterionių Konsistorijos posėdžio, ịvykusio 1940 m. sausio mèn. 9 dieną protokolas. (1940). Lietuvos evangeliku liuteronu bažnyčios konsistorijos protokolu knyga. (1935-1941). Konsistorijos archyvas (puslapiai nenumeruoti).

Lietuvos Evangelikų Liuteronių Konsistorijos 1942 m. balandžio 30 d. posėdžio protokolas. (1942). Gauti raštai 1941-1944. Jono Kalvano archyvas (puslapiai nenumeruoti).

Lietuvos Evangelikų Liuteronių Konsistorijos 1943 m. rugsėjo 15 d. posėdžio protokolas. (1943). Gauti raštai 1941-1944. Jono Kalvano archyvas (puslapiai nenumeruoti).

Maldu ir giesmiu knygele. (1956). Vilnius: Vaizdas.

Pagérintos giesmjû-knygos. (1930). Klaipèda: Lituanija.

Petkūnas, D. (2012). Prieškario Liuteronų Bažnyčios pastangos išleisti giesmyną bendrine lietuvių kalba. Res humanitariae. Klaipėda: Klaipėdos universiteto leidykla, 2012, p. 7-26.

Reformatų konsistorijos posėdžiai. (1948, 1957, 1958). Lietuvos ev. reformatų konsistorijos posédžiu protokolų knyga 1946-1995. Konsistorijos archyvas (kopija).

Sprogis, J. (1938). Pietizmas ir dwasiški surinkimai Mažojoje Lietuvoje. Jagomasto Lietuwiszkos Kalendros 1939. Tilžè: Lituania, p. 48.

Tauragès kun. A. Vymerio ir parapijos tarybos raštas konsistorijai. (1938). Po karo 1944 m. spalių mèn. surinkti iš rūsio rusų kareiviu išdraskytų rastu liekanos. Jono Kalvano archyvas (puslapiai nenumeruoti).

Tauragès parapijiečiu skundas Lietuvos Respublikos ministrui pirmininkui. (1939). LCVA f. 391, a. 4, b. 761.

V. Gaigalaičio laiškas E. Leijeriui, 1943 m. gegužès 26 d. (1943). Gauti raštai 19411944. Jono Kalvano archyvas (puslapiai nenumeruoti). 


\section{THE FIRST ECUMENICAL EVANGELICAL HYMNAL IN LITHUANIA AND CHALLENGES TO ITS IMPLEMENTATION}

\section{Darius Petkūnas}

Summary

In 1937, the consistory of the Lithuanian Lutheran Church initiated a hymnal project to provide the congregations with a book which would replace outmoded and no longer easily understandable terms with modern Lithuanian. They envisioned the publication of an ecumenical hymnal in cooperation with the Lithuanian Reformed Church and incorporating hymns reworked in modern speech by Reformed Minister Adomas Šernas. As public knowledge of the project spread, opposition began to increase and complaints were received from lay preachers and church members who thought the old words to be sacrosanct. Angry letters filled the mailbox of the Ministry of Education. This led the consistory to revise its initial plan to replace the old book and instead leave it to pastors and congregations to decide which book to use.

The project was finally abandoned for several reasons. Most of the members of the consistory were forced to leave the country in the repatriation of 1941 and those who replaced them had little interest in the production of an ecumenical book, especially one making use of hymns radically revised.

In 1942, the Reformed collegium decided to take up the project and publish an abridged work, entitled, Evangeliku giesmynas su maldomis (Evangelical Hymnal with Prayers), with 388 hymns. Basically, it was the same project as the old Lutheran consistory had conceived it, incorporating the hymn revisions of Šernas and the consistory's hymnal commission. The question of its use in Lutheran congregations was again addressed by the Lutheran consistory in 1943. It would not approve this book for general use, but ruled that it could be used in the congregations in Kaunas and Telšiai.

The Lutheran clergy decided to form a new hymnal commission for the purpose of publishing an up-to-date hymnal which would be Lutheran in character and content. The model for this hymnal would be Pagerintos giesmiu 
knygos (Improved Books of Hymns), the hymnal commonly used in Lithuanian Lutheran congregations at that time. Hymn texts were to be revised only to the extent of removing barbarisms and older Lithuanian words no longer in common use. Work had not yet been completed when the Red Army reentered Lithuania in 1944 and the subsequent repressive measures of the new communist government made it impossible to complete the project.

Introduction of the hymnal Evangeliku giesmynas su maldomis in Reformed congregations did not go smoothly. Some congregations indicated that they still much preferred the Reformed hymnal which had been prepared in 1910 by Stanislovas Dagilis. The collegium decided that the first step in gaining acceptance for the new book was to use it side by side with the old hymnal. However, the apostasy of Šernas, who declared in 1964 that he was an atheist, contributed to the wholesale rejection of the 1942 book. It lay unused until the 1986 when the old hymnals were worn out and in need of replacement. It was only then that the Reformed decided to make the 1942 book their official hymnal. A reprint edition of it appeared in 2001.

In 1947, congregations of the Lutheran Church in Exile in Germany used some of the revised hymns of the 1942 book in its own edition of Evangeliku giesmynas su maldomis (Evangelical Hymnal with Prayers). In 1957, this book was expanded. It provided source material used in the preparation of the new 2007 Lithuanian Lutheran hymnal, Krikščioniškos giesmès (Christian hymns). 